\title{
Evaluation of Use of Social Media in Marketing Communication Activities of Institutions
}

\author{
Ünal Çimçek, Selin \\ Marketing and Advertisement Department/ Honaz Vocational School/ \\ Pamukkale University/ Turkey
}

Doi: 10.19044/esj.2018.c4p4 URL:http://dx.doi.org/10.19044/esj.2018.c4p4

\begin{abstract}
Rapidly evolving technology has led to the differentiation of communication tools used by institutions and brands in marketing communication activities. Social media with low-cost, fast feedback providing a possibility to access large masses in a shorter time with Web 2.0 technology has become a preferred tool for brands.

In this study the concepts of social networks and social media is explained within the scope of communication studies, in relation with public relations, advertisement, and sales promotion. In the scope of the research; it has been benefited from the statistical information inferred from the data based on Facebook, Twitter, and Instagram during 1-31 January 2018 period by SocialBrands, which measures more than 25 thousand brands' social media performances. Social media marketing communications studies of two of the successful brands in home decoration sector in Turkey, Madam Coco and English Home, have been analyzed by the data of SocialBrands. It has been tried to explain that brands become more successful in brand communications with social media through which they find the measurable and fast opportunity to determine their target audience.
\end{abstract}

Key Words: Social Media, Marketing Communication, Brand

\section{Introduction}

Today, social media, which has appeared with the development of Internet and Web 2.0 technology, has become an important tool that brands use in their communications with their customers. Thanks to social media and Internet, consumers have information about institutions, products, and brands. Marketers want to achieve success by putting existing and potential customers into interaction with the brand (Clow and Baack, 2016: 8).

Social media, which has entered our lives in recent days with the decreasing effect of advertisement, inadequacy of public relations on certain 
points, inability of communication methods such as promotion and social responsibility to always create the desired effect, and the rising value of marketing communication, confronts us as a unique tool in communication with consumers (Akar, 2010: 40). Institutions tend to attain measurable gains in brand awareness, brand loyalty, and market share in sales.

One of the biggest benefits that social media provides to institutions is the possibility to observe consumers. Institutions which gain a chance of observing all the actions performed by their consumers such as; which sites they enter, which products or advertisements they click on, which shares they like, through the use of specific programs also carry out their marketing studies as interactive and customized (Denetçi, 2015: 3).

\section{Social Media}

Social media, also referred to as the Web 2.0, is online technologies and applications in which people share their views and experiences. Social media can be also stated as the medium in which different contents, such as texts, audios and videos, are broadcast (Wikipedia, 2011). The best way of expressing the social media is that social media is, in fact, only about being human. Sharing the ideas, exchanging opinions, cooperating, thinking, trading, performing hard debates and speeches, finding the people who might become good friends, mates and beloveds, are already the acts over which humankind has constructed civilizations. In that sense, social media has rapidly spread over not because it is an excellent information technology but because it leads humankind to be like itself. (Mayfield, 2008: 14).

The number of its users is increasing day by day with its possibility of being constantly updated, openness to multi-use, and possibility of virtual sharing. In social media, users are not only able to perform consumption, but also production. Many organizations build their business strategies through social media. Social media environments can basically be grouped into 7 groups (Onat and Alikılıç, 2008: 1111-1143): E-mail groups, blogs, forums, corporate intranets, extranets, instant messaging services, social network sites.

Groups of people connected to each other over a single common resource constitute social networks. Social networks play a big role on the direct transference of individuals' ideas (Güçdemir, 2017:25).

Social networks supply many marketing objectives of the brands, such as creating asset by forming brand identity, constituting contents offering social value, meeting with community members, communicating, and offering a reason to share (Tuten, 2008:53).

Social network sites, which witness a very important participation and an intensive usage among social media tools, are web based services enabling individuals to create a public or semi-open profile within a confined system, to speak to the people on the lists of the other users they share the connection 
with, to view their contact lists, to make transitions from there, and enabling other individuals in the system to also perform these actions. The most important feature that makes social network sites unique is in addition to giving individuals the opportunity to meet strangers, it also gives them the opportunity to communicate with the people they are connected with in the real world, and to make their social networks visible. Thus, it is made possible to establish links between individuals that they can not otherwise form. This kind of friendship ties happen among people who know each other in real life, but who have weak ties between each other. In the vast majority of social networking sites participants are primarily communicating with people in their current social network, rather than seeking to meet new people (Boyd and Ellison, 2008: 211).

The use of social networks is increasing day by day. "Digital in 2017 Global Overview" report which was published by "We are Social and Hootsuite" provides important information on the Internet and social media user statistics (www.digitalajanslar.com/internet-ve-sosyal-medya-kullanic1istatistikleri-2017/). The 106 page report, prepared from the data collected from 238 countries, contains up-to-date information about the development of the Internet and digital.

\section{According to the research,}

$60 \%$ of Turkey's population, 48 million people, are social media users. This number is only for single use. The number of people connected to social media from mobile is 42 million. Considering the growth, it has been observed that the number of Internet users increased 2 million with 4\%, and the number of active social media users increased 6 million with 14\% in Turkey since January 2016. Users spend an average of 7 hours on the computer, 3 hours on connecting to the Internet via phone, and 3 hours on the social media platforms during the day. The average time spent on TV is 2 hours. It has been also noted in the report that the use of Internet and social media in developed countries is high, while in undeveloped regions such as the African continent, individuals use the Internet and social media at a very low level.

According to the report, Turkey's social media and Internet usage rate with $60 \%$ is at an average value between Asia with $46 \%$ and Europe with $76 \%$.
According
to
We
are
Social
2017
data,

(https://pazarlamailetișimi.com/turkiyenin -digital-kullanim-aliskanliklari$\underline{2017 /)}$ in Turkey, the most widely used media is YouTube, and Facebook follows it with a small difference. Other popular social media channels are; Instagram and Twitter.

With the development of the youtuber concept, many people began to share their contents and generate incomes through the videos. Although there 
are many brands and people who produce content for Youtube, there are also content agencies focused on this area. According to 2016 demographic data, it has approximately 52 million active users. $48 \%$ of those are adult parents. The majority of the answers to the question of what Youtube is used for is as follows; $58 \%$ for fun, $47 \%$ for learning, $25 \%$ for original content, $23 \%$ for product research. Brands are producing contents on YouTube which emphasize on the limited scope of products and services related to the interests of their target groups.

The benefits content sharing sites provide to businesses and brands can be addressed under two main headings. These are (Ryan and Jones, 2009: 160):

-Learning what are the interests of the target market: The ability to understand the likes and dislikes of the target market can be obtained through the analysis of the popularity of the messages in the content sharing sites and reading the user comments, and these can be combined in content creation.

-Being a ready tool for content distribution: Content sharing sites are an ideal tool for rapid distribution of digital media content. Actually, all digital marketing is evolving around the micro discipline of YouTube and viral video content. On the other hand, services which allow people to upload, share, and discuss their slides in a variety of different settings such as Slideshare, are another example of content sharing sites. All these and similar content sharing sites make it possible to share and discuss with other people if desired, in an integrated way with other social media tools by making the content publicly available (Akar, 2011: 96). When the social networks widely used today are classified:

\section{Facebook}

It is a social networking site which was founded in 2004 by a student at Harvard University, and spread all over the world. According to a statement made by Facebook in the fourth quarter of 2016, the number of monthly users around the world approached to 2 billion (www.cnnturk.com/teknoloji). $72 \%$ of its users are adult users (Pew Research Center, 2015).

According to statistics created by HubSpot (2017) showing how marketers have expanded their reach with social media (http://www.pazarlamasyon.com/pazarlama/pazarlamacilar-icin-sosyalmedya-kullanim-istatistikleri/); only $45 \%$ of the marketers think that their communication work on Facebook is effective and fruitful (Social Media Examiner, 2015).

Facebook posts with photographs get two times more interaction than the ones without photographs (http://buzzsumo.com/knowledge/analyzefacebook-posts-and-pages/). $70 \%$ of the Facebook users sign in daily while $43 \%$ sign in a few times a day (Pew Research Center, 2015). Facebook sends 
$82 \%$ of its social media traffic to longer posts, and $84 \%$ of it to shorter news articles (Pew Research Center, 2016). $63 \%$ of the Facebook and Twitter users say that each platform acts as an additional resource for news on matters apart from events, friends, and family (Pew Research Center, 2015). $74 \%$ of the people say they use Facebook for professional purposes (HubSpot, 2017). Content consumption on Facebook has shown an increase at the rate of $57 \%$ (HubSpot, 2016). $76 \%$ of the people use Facebook pages to find an interesting content (HubSpot, 2016).

\section{Instagram}

Instagram, which is especially used by young people, shatters records with its share of 55 million photos a day. Brands are using it extensively in campaign management and promotions. 28\% of adults use Instagram (Pew Research Center, 2015). 59\% of Instagram users are on the platform on a daily basis, while $35 \%$ of them are visiting several times a day (Pew Research Center, 2015).

Instagram, which was first introduced in October 2010 on the iPhone platform, reached the first 1 million users in December 2010. In September 2011, however, it reached over 10 million users. The number of the users of the application, which was also published for Android platform in April 2012, was 30 million on iPhone at the same date. It reached to; 100 million in February 2013, 200 million in March 2014, 400 million in September 2015 and 500 million user numbers in June 2016 (www.mobilhobi.com). More than 95 million photos and videos are shared daily in Instagram (Instagram, 2016). In April 2017, it reached 600 million users.

\section{Linkedin}

It is a social network chosen by users to create networks, establish new business connections and be aware of the innovations. $25 \%$ of the adults use Linkedin (Pew Research Center, 2015). Linkedin is the only significant social media platform where the utilization rates in the 30-49 age group are higher than in the 18-29 age group (Pew Research Center, 2015). 46\% of the adults graduated from universities use Linkedin (Pew Research Center, 2015). 32\% of the working adults are Linkedin users, and besides that another \%14 is consisted of unemployed (Pew Research Center, 2015).

\section{Twitter}

It is one of the strongest representatives of the communication network. It is also used as a good advertising tool. On Twitter, where more than 6 tweets are posted per second, more than 500 million tweets are entered per day (www.seokursu.com.tr/sosyal-medya-siteleri). In Twitter, messages about the agenda and life are constantly updated. $23 \%$ of the adults use 
Twitter. (Pew Research Center, 2015). 30\% of the Twitter users are under the age of 50, and $11 \%$ of them are over 50 years old (Pew Research Center, 2015). Twitter accounts for $16 \%$ of the posts made by long articles on social websites, and 14\% of the shorter news articles (Pew Research Center, 2016).

\section{Use of Social Networks in Marketing Communications}

At the heart of marketing communication are the efforts to inform consumers about goods and services produced by institutions, to convince them, to direct them to a certain behavior and to remind them. Marketing communication; is defined as an institution's communication process consisting of consciously programmed and coordinated activities aimed at persuading the customer and carried out under the supervision of the producer / marketer with the purpose of facilitating the sales of the products or services.

Considering the historical development of marketing communications, it is possible to respectively talk about personal sales, advertisement and public relations, Following the sales promotion procedures that have been added to these methods, direct marketing has been added as the fifth element to the traditional quadruple division (Mucuk, 1997).

It is seen that marketers use social networks for many reasons in their marketing communication applications (www.socialmediaexaminer.com, 2013):

- Interacting with fans

- Increasing the brand visibility

- Finding a point of interaction with the customer

- Increasing site traffic

- Emphasizing the leading aspects.

-Strengthening the brand image

- Rising in the search rankings

-Attracting the customer intelligence

-Creating loyal fans

-Increasing the sales

Brands organize gifts, draws, and competitions in order to increase brand visibility by having more likes and shares on social networks. Although there isn't always a need for gifts and promotions to interact with fans and provide more people to follow, this method increases the interest in the brand. With customer interactions, users enable the brand to be announced through word of mouth communication by sharing their experiences about the brands.

Social networks can also provide traffic at the brand's website. By giving the website of the brand in the messages on social networks, users can be led to visit the website and get detailed information about the brand and the campaigns. In addition to the purpose of providing only information about 
brands, social networks can support brand image enhancement by also doing social responsibility studies.

Social networks can help to ensure that the brand rises in search rankings with the support of search engines. These rises occur for two reasons: Firstly, since most of the search engine algorithms analyze the numbers of being tagged and written, the brand name rises to the top as people start to use the brand's name more often in the social media networks. Secondly, if the published content or the comments made about the brand overlap with keywords, the quality of interaction increases, and thus, search engines provide a significant amount of credibility to the brand (Clow and Baack, 2016: 259).

Since the consumers are both producers and consumers in social media networks, it is important to listen the consumers in order to specify trends and identify problems. Being able to respond quickly to negative feedbacks, and replying the questions also affect the brand image.

Listening to what is spoken on social networks also supports identifying the brand advocates. When examining social interactions, three characteristic features of brand advocates are pointed out: Behavioral commitment, emotional ties, quality communication skills. Advocates often make behavioral commitments to the brand. They buy the brand regularly and frequently. They establish an emotional connection with the brand. Suggestions of this profile, complimenting the brand by praising, is very important. They must have good communication skills also while expressing their feelings and thoughts (Pruden and Vavra: 2014).

It is seen that brands have increased their sales by benefiting from social networks to reach a loyal customer profile and to provide brand dependency. Users make suggestions and share ideas on social networking sites. It is seen that customers have repeatedly investigated the ideas of others when they thought of buying goods and services. In fact, $78 \%$ of the global consumers believe and trust other people's suggestions for goods and services compared to another setting. The opinions of others are seen as more objective than the institutions' own marketing messages. Consumers use online resources, including social networks, to find the ideas of others. Members of social networks perform two tasks. These are providing content and consuming content. Creators of the content are typically and extremely tied to consumers as a result of effectiveness. If the right influencers are reached by a message (which might be viral), it is perceived as valuable. This is extremely powerful for marketers since it feels that the information is not transmitted to the user and the user is sent by a trusted friend on a secure network(http://www.redbridgemarketing.com/social_networking the basics. pdf). 
Company executives use social networking sites in marketing communication strategies since they affect buying behavior. Customers also follow brands for reasons such as getting information about products and services, recalling activities, draws, promotions, getting feedbacks, joining fan communities, making purchases, and complaining (Garibian, 2013: 10336).

It is seen that brands are following marketing communication strategies in social networks where they can effectively communicate with their customers. The most effective of these strategies is creating content. Methods to provide content shares about a brand should be used. For instance, organizing competitions, money refund, giving coupons, giving gifts etc. Marketers who care about value added feelings can create a content sharing environment that offers something that will enable customers to feel special.

\section{Usage of Advertisement in Social Media}

Advertisement, which is an important element of the marketing combination, is the presentation of the goods, services, or ideas to large masses for a fee, in a non-personal way with the aim of announcement and adoption. Apart from traditional media, advertisement is also effectively used in social networks, which we call as new media.

Advertisements broadcast on traditional media are uploaded on social media, on Youtube, and they can be published as links or videos on Twitter and Facebook. The Coca Cola brand delivers messages on Facebook to approximately 36 million 180 thousand people worldwide, which intensify their needs and desires, create awareness, and appeal to their emotions (Özdemir, 2013: 323).

RTB House announced the results of advertisements given on social media and classic websites by sharing the analysis of data collected from 40 countries. It was revealed that the rate of users who clicked on the ads per view is higher in social media. Turkey comes at the top of the countries where the most striking difference can be seen in high click-through rate on social media. In Turkey, advertisements on social media is clicked $110 \%$ more compared to classic websites (www.pazarlamasyon.com).

There are four basic reasons why social networks play a significant role in advertising strategy (Todi, 2008: 52):

-Broad access: More than half of the world's population is an Internet user. Internet users are increasingly devoting time to activities done with social connections. By integrating social networks in advertising strategies, companies can easily reach a large user base. Social media advertisement, also referred to as social network advertisement, provides opportunities for brands to reach both mass and niche markets (Tuten, 2008:42).

- Lower costs: Advertising over social media is very cheap compared to traditional media. Very cheap promotions with a wide range of access can 
be made. In recent years, successful advertising campaigns have been made on YouTube and Facebook.

-Advertisement with a target: In a way not seen in other advertising mediums, advertisers are able to advertise target-specific ads, and to access vast amount of information about users' interests.

-Time spent in the virtual environment: Users spend more and more time on social media instead of the traditional media. Advertisers are looking for ways to reach consumers who spend more time in the virtual environment (Todi, 2008: 52).

Social media advertising offers important opportunities at the points of ensuring the interaction of consumers with the brand, the determination of what the brand means for consumers, detecting the inconvenience of online customers, and the determination of what character the brand will have (Tuten, 2008: 14).

\section{Usage of Public Relations in Social Media}

Increasing competition among institutions in today's modern world requires the most effective introduction of the products or services that institutions produce. For this reason, instead of just advertising for sales purposes, public relations activities with the aim of improving the image of the organization, brand, product or service by developing positive relationships with the target audience are more prominent. Public relations studies which is defined as a distinctive management function that helps establishing and maintaining mutual communication, interaction, acceptance and cooperation between an institution and its target audience, has begun to differ, especially as the Internet begun to progress (Yeniç1kt1 2016: 97).

Digital public relations, which is strategic, fast and result oriented, has become a preferred medium for communication. It is preferred by the institutions in order to strengthen the corporate reputation in social networks and to promote its products and services.

According to a research conducted by PRCA; 55\% of the institutions allocate $16 \%$ of their budgets for digital public relations activities. These activities include; online advertising, web design and structuring, content creation, social networking strategies, and increasing the impact of blog writers (Digital PR Report 2015).

Institutions seeking to perform public relations aims, such as establishing links with customers through social media, establishing and developing brand awareness, strengthening positive image, started to use social media platforms such as blogs, micro-bloggings, wikis, social networking sites, media sharing sites, social marking and tagging sites, podcasting and virtual worlds intensively (Taşdemir 2011: 653). 
The positive effects that social media provides to institutions' public relations activities are as follows (Alikılıç 2011: 17-19):

- New stakeholders as new target audience: Social media creates new online communities, each of which can be the new social stakeholders of the organization.

- Direct communication and interaction with social stakeholders: Institutions and brands get into direct communication and interaction with social stakeholders without intermediaries and filters through virtual environments where contents are created by users, such as social networks, websites, videos, photo and video sharing sites, blogs, and so on.

- The spread of posts: Social media tools are important mass media tools for the purpose of spreading positive messages.

- User-driven content sites as mixed media: Firms can use user-driven content sites, namely, social media environments (blogs, forums, newsgroups, virtual worlds, social networks, etc.) as well as traditional mixed media, such as television, radio, newspapers.

- Business collaboration with the target group: In social media environments, people produce messages by presenting ideas about brands, institutions, products and services. Public Relations specialists can cooperate with the new stakeholder groups defined in the social media environment by listening to the messages created by them and giving feedbacks to these messages.

- Performing feedback and corrective / preventive actions: Listening to what is said about them can earn institutions and brands a lot. Feedback coming from online stakeholders can be identified and corrected before it is too late. Just as quick feedbacks can be obtained, fast corrective / preventive actions can also be planned.

- Participation and adaptation: By observing social media, and providing participation, brands can ensure participation to any kind of environment related to themselves. Participation in these groups is a great opportunity for companies to endorse their new breakthroughs, new products, new strategies and policies to them.

- Creating a network: Creating a network in online environments is a new public relations tool. This means that while firms form strategies and tactics for communication and public relations, they find and join to the networks that are most suitable for them to build relationships.

- Confidence: The most important element among institutions and stakeholders is confidence. With the creation and dissemination of content by users themselves, they have actually taken possession of a considerable force. With the confidence this power gives, they have begun to communicate with each other with higher loudness and have gained the trust of each other in particular. 
- Corporate reputation: In order to build and protect corporate reputation, it is primarily necessary to identify how it is perceived by all stakeholder groups. Institutions can catch the opportunity of protecting and increasing their reputation by maintaining effective communication with millions of people who are effective in the online environment.

\section{The Usage of Sales Promotions in Social Media}

Sales promotions; are impermanently carried out marketing activities excluded from advertisement, personal sales and public relations activities, seizing the purchasing behavior of the consumer and increasing the effectiveness of the business. Brands make various sales promotions in order to promote product sales in social media. Although there is focal point pricing in sales promotions, activities towards creating brand awareness and improving the brand image are also carried out.

In order for the brand to reach its marketing communication goals, marketing teams design promotional programs. In the early stages of the product life cycle, there are matchings done with promotions, tentative purchases, and other activities focusing on brand awareness. Further objectives are mentioned as strengthening brands, increasing consumption, facilitating competition, and changing into new markets (Clow and Baack 2016: 37).

Social media is particularly a popular area for competitions and draws. It is being preferred for its features of being both fast and cheap as well as being easily controlled and obtained knowledge from. Consumers strengthen their ties with the brand by participating in contests, games, draws organized in social media tools.

The latest trends in contests and draws contain social media. Microsoft, Sephora, NASCAR, Comcast, McDonalds have organized twitter competitions or used twitter or other social media tools with the purpose of joining in a draw and competition. Marketers use competitions and draws in order to trigger a viral rumor about a brand (Morrissey 2009).

\section{The Method of the Research}

SocialBrands algorithm, which uses the advanced technology of BoomSonarSuite, a smart business platform offering specific social media tracking management and analysis results, and detailed data of BoomSocial, analyzes all social media activities of more than 25 brands with abiding to the big data principle. More than 30 criteria in total such as; the total number of interactions of the pages, the number of fans, the fan increase, the growth stability, the distribution of the interactions according to the messages, the likes, the comments, the sharing, the retweet rates, the number of messages the page has distributed throughout the month, the usage rates of different 
message types, constitutes the basis of the algorithm which analyzes brands statistically and objectively (www.socialbrandsturkey.org). SocialBrands, which identifies the most powerful brands on Facebook, Twitter and Instagram entirely based on data, examines the performance of more than 25 brands displayed on social media each month.

In the study, the marketing communication activities of MadameCoco, which is ranked 1st in the household and decoration sectors among the brands which made the most successful rankings, and English Home, which is ranked 18 th on the top 100 list of the same sector in social media, is analyzed according to SocialBrands data between January 1-31, 2018.

\section{Findings and the Evaluation}

Accounts reviewed: 25094

Messages reviewed: 1,443,240

Interactions investigated: 799.808.475

The time period examined: January 1-31, 2018

\section{Madame Coco}

Facebook 2nd

Twitter 3rd

Instagram 1st

\subsubsection{2 follower 1.455 .672 interaction \\ 54.909 follower $\quad 42.806$ interaction \\ 1.705.361 follower 1.568 .489 interaction}

Madame Coco, which is ranked 1st in the top 100 rankings, is also ranked 1th among 102 brand accounts in all social networks on "home and decoration" sector, which is a sub-sector within the durable consumption main sector.

$\begin{array}{lll}\text { Top 100 } & \text { January 2018 } & \text { December } 2017 \\ \text { Social Score(\%) } & 88.37 & 87.49 \\ \text { Facebook } & 90.07 & 90.51 \\ \text { Twitter } & 79.39 & 77.06 \\ \text { Instagram } & 95.65 & 94.92\end{array}$

\section{English Home}

Facebook 22nd

Twitter 294th
1.597.414 follower

39.315 follower

1.840.005 follower
238.045 interaction

1865 interaction

757.239 interaction

English Home, which is ranked 18th in the top 100 rankings, is ranked 2nd on Facebook and Instagram, and 4th in Twitter among 102 brand accounts in "home and decoration" sector, which is a sub-sector within the durable consumption main sector.

Top 100

Social Score $(\%)$

Facebook
January 2018

88.37

90.07
December 2017

87.49

90.51 
$\begin{array}{lll}\text { Twitter } & 79.39 & 77.06 \\ \text { Instagram } & 95.65 & 94.92\end{array}$

As it is also seen in the analysis results, it is observed that the brands in the home and decoration sector have given intensive use of Instagram especially in marketing communication. Instagram, which is a photo and video sharing site, is also used extensively in mobile applications.

In Instagram, the length of the video content is sent as 15 seconds, and when the content is scrolled the image starts to play automatically. Videos become also beneficial for organizations by adding extra voice and image to communication, especially in telling their brand stories (Hellberg 2015: 21). It also provides a function known as "hashtag", which provides ease of displaying photos and videos about the institution's products and services. Users are able to see all the photos and videos related to these hashtags by clicking on these hashtags.

It has been observed that consumers' expectation and complaints are learned from the comments left under the photographs, and there have been efforts to strengthen brand loyalty by increasing follower numbers through sales promotions like "tag your friends and win a gift".

Statements which have a triggering effect on customers, like "do not miss it for just 3 days, just wait for our surprise at 14:00, discounts are only specific to this day", are the advertisement studies both companies use in their advertisement strategies to direct their customers to sales. Product promotions, gifts, promotions, campaigns, draws and competitions are intensely used by both brands on social networks.

It has been observed that messages such as, "like the visual, tag your friend and get the chance of winning a gift for your friend and yourself" get more likes and shares than product promotion messages, discount campaigns and the other messages.

The method to interact with customers through promotions and gifts on social media is observed in both brands. Customer interactions also provide the opportunity for word of mouth communication. It is seen that both MadameCoco and English Home use "tag your friend" application intensively. Recommendation of the product by a customer to a friend or conveyance of the experience about it is more valuable than the hundreds of promotions the brand will make.

MadameCoco, which makes the intensive use of the feature of customers' being both content producers and content consumers on social media, receives information by asking questions to be completed by customers in order to learn what customers think about the brand. "MadameCoco is a love, because ...". At the same time, it tries to improve its brand image by sharing its achievements and its awards with consumers. It has been observed that both brands share their work on Facebook, Twitter and Instagram 
concurrently. When the interaction networks are examined, it has been concluded that Instagram is in the 1st place, Facebook is in 2nd, and Twitter's likes and shares are less than the others.

When the Madame Coco and English Home social media brand accounts are examined in general, it has been observed that message integrity is provided, applications supporting each other are concurrently broadcast in social media, and messages with the aim of strengthening the brand loyalty and brand perception are used.

Brands which use the social media effectually have good communication with consumers, and they carry out successful marketing communication activities in many fields from consumer complaints to product promotions, campaign announcements to special applications. It can be said that social networks used in social media are preferred communication mediums by brands because of the reasons such as; freedom of their message content, measurability, being fast and economical, and the ease of detecting the target group.

\section{References:}

1. Akar, E. (2010). Sosyal Medya Pazarlaması, Sosyal Webde Pazarlama Stratejileri, Efil Yayınevi, Ankara

2. Alikılıç, Ö.A. (2011). Halkla İlişkiler 2.0 Sosyal Medyada Yeni Paydaşlar, Yeni Teknikler, Efil Yayınevi, Ankara

3. Boyd, D. M., Ellison, N. B. (2007). Social Network Sites: Definition, History and Scholarship, Journal of Computer Mediated Communication, 13(1)

4. Clow, K.E., Baack, D. (2016). Integrated Advertising, Promotion and Marketing Communication, 7. Edition, Pearson, USA

5. Denetçi, S. (2015). Markaların Sosyal Medya Yönetimi, Kriter Yayınları, İstanbul

6. Garibian, 1. (2013). Digital Influence: Blog Beat Social Networks for Driving Purchases, MarketingProfs, Www.marketingprofs.com/charts/print/2013/10336

7. Güçdemir, Y. (2017). Sosyal Medya, Halkla İlişkiler Reklam ve Pazarlama, Derin Yayınları, İstanbul

8. Hellberg, M. (2015). Visual Brand Communication on Instagram: A Study on Consumer Engagement, Master Thesis, Hanken School of Economics, Helsinki

9. Kalender, A. (2008). Halkla İlişkiler Kavramlar, Tanımlar ve Uygulama Alanları, Ahmet Kalender ve Mehmet Fidan (eds), Halkla İlişkiler, Tablet Yayınları, Konya

10. Mayfield, A. (2008). What is Social Media?, Available at http://freepdfs.org/pdf/what-is-social-media 
11. Morrissey, B. (2009). Brand Sweepstakes Get Twitterized Adweek www.adweek.com

12. Mucuk, İ. (1997). Pazarlama İlkeleri, İstanbul: Türkmen kitapevi

13. Onat, F., Alikılıç, Ö. A. (2008). Sosyal A ̆̆ Sitelerinin Reklam ve Halkla Ilişkiler Ortamları Olarak Değerlendirilmesi, Journal of Yaşar University, 3(9), 1111-1143

14. Özdemir, K. (2013). Bir Iletişim Aracı olarak Sosyal Medyanın Tutundurma Karması İçerisindeki Yeri Üzerine Bir Inceleme, Süleyman Demirel Üniversitesi The Journal of Faculty of Economics and Administrative Sciences, Vol.18, No.1, pp.323-337

15. Pruden, D., Vavra, T. (2014). How to Find and Activate Your Best Potential Advocates, http://smartblogs.com/social-media/2014

16. Ryan, D. and Jones, C. (2009). Understanding Digital Marketing: Marketing Strategies for Engaging the Digital Generation, Kogan Page, London \& Philadelphia

17. Taşdemir E. (2011). Bütünleşik Pazarlama İletişimi Temelinde Sosyal Medya, E-Journal of New World Science Academy, 6(3), 645-665

18. Todi, M. (2008). Advertising on Social Networking Websites, Wharton Research Scholars Journal, 52

19. Tuten, T.L. (2008). Advertising 2.0: Social Media Marketing in Web 2.0 World, Westport: Greenwood Publishing Group Inc.

20. Yeniçıktı, N.T. (2016). Halkla Ilişkiler Aracı Olarak Instagram: Sosyal Medya Kullanan 50 Şirket Üzerine Bir Araştırma, Selçuk İletişim Dergisi, 9(2), 92-115

21. http://buzzsumo.com/knowledge/analyze-facebook-posts-and-pages/

22. wWw.cnnturk.com/teknoloji

23. www.coca-colaturkiye.com.tr

24. www.digitalajanslar.com/internet-ve-sosyal-medya-kullanıc1istatistikleri-2017/

25. www.instagram.com

26. www.mobilhobi.com

27. https://pazarlamailetişimi.com/turkiyenin -digital-kullanimaliskanliklari-2017/

28. www.pazarlamasyon.com

29. www.pewresearch.org

30. http://www.redbridgemarketing.com/social_networking_the basics.p df

31. http://released.com/576a/digitalreport2015

32. www.seokursu.com.tr/sosyal-medya-siteleri

33. www.socialmediaexaminer.com

34. www.venturebeat.com

35. www.wikipedia.com/2011 